\title{
Structural and Functional Properties of Platelet-Derived Growth Factor and Stem Cell Factor Receptors
}

\author{
Carl-Henrik Heldin and Johan Lennartsson \\ Ludwig Institute for Cancer Research, Uppsala University, SE-751 24 Uppsala, Sweden \\ Correspondence: c-h.heldin@licr.uu.se
}

The receptors for platelet-derived growth factor (PDGF) and stem cell factor (SCF) are members of the type III class of PTK receptors, which are characterized by five Ig-like domains extracellularly and a split kinase domain intracellularly. The receptors are activated by ligand-induced dimerization, leading to autophosphorylation on specific tyrosine residues. Thereby the kinase activities of the receptors are activated and docking sites for downstream SH2 domain signal transduction molecules are created; activation of these pathways promotes cell growth, survival, and migration. These receptors mediate important signals during the embryonal development, and control tissue homeostasis in the adult. Their overactivity is seen in malignancies and other diseases involving excessive cell proliferation, such as atherosclerosis and fibrotic diseases. In cancer, mutations of PDGF and SCF receptorsincluding gene fusions, point mutations, and amplifications-drive subpopulations of certain malignancies, such as gastrointestinal stromal tumors, chronic myelomonocytic leukemia, hypereosinophilic syndrome, glioblastoma, acute myeloid leukemia, mastocytosis, and melanoma.

\begin{abstract}
The type III tyrosine kinase receptor family consists of platelet-derived growth factor (PDGF) receptor $\alpha$ and $\beta$, stem cell factor (SCF) receptor (Kit), colony-stimulating factor-1 (CSF-1) receptor, and Flt-3 (Blume-Jensen and Hunter 2001). Members of this receptor family are characterized by five Ig-like domains in their extracellular part, a single transmembrane domain, and an intracellular part consisting of a rather well-conserved juxtamembrane domain, a tyrosine kinase domain with a characteristic inserted sequence without homology
\end{abstract}

with kinases, and a less well-conserved carboxyterminal tail. The ligands for these receptors are all dimeric molecules, and on binding they induce receptor dimerization. Although the overall mechanisms for the activation of the type III tyrosine kinase receptors and the signaling pathways they induce are similar, the receptors are expressed on different cell types and thus have different functions in vivo.

Here we will describe the structural and functional properties of the PDGF receptors and Kit.

Editors: Joseph Schlessinger and Mark A. Lemmon

Additional Perspectives on Signaling by Receptor Tyrosine Kinases available at www.cshperspectives.org

Copyright (C) 2013 Cold Spring Harbor Laboratory Press; all rights reserved; doi: 10.1101/cshperspect.a009100

Cite this article as Cold Spring Harb Perspect Biol 2013;5:a009100 
C.-H. Heldin and J. Lennartsson

\section{PDGF RECEPTORS}

\section{Ligand-Binding Specificities of PDGF Receptors}

The PDGF family consists of five members (i.e., disulfide-bonded dimers of homologous A-, B-, C-, and D-polypeptide chains, and the AB heterodimer) (Heldin and Westermark 1999). The PDGF- $\alpha$ receptor binds all PDGF chains except the $\mathrm{D}$ chain, whereas the $\beta$ receptor binds PDGF-B and -D; thus, the different PDGF isoforms can induce $\alpha \alpha-, \alpha \beta$-, or $\beta \beta$-receptor dimers (Fig. 1). The ligand-binding sites are located in Ig-like domains 2 and 3 (Heidaran et al. 1990; Lokker et al. 1997; Miyazawa et al. 1998; Shim et al. 2010); however, ligand-induced receptor dimerization is stabilized by direct receptor-receptor interactions in Ig-like domains 4 and 5 (Omura et al. 1997; Yang et al.
2008). The latter interactions are important because they orient the receptors so that their activation by autophosphorylation in trans is facilitated. Binding of vascular endothelial growth factor (VEGF)-A to PDGFR- $\alpha$ and PDGFR- $\beta$ has been reported (Ball et al. 2007), but the physiological significance of this finding remains to be elucidated.

Ligand stimulation results in homo- as well as heterodimerization of PDGF- $\alpha$ and $-\beta$ receptors; the different dimeric receptor complexes have overlapping but slightly different signaling capacities (see further below). However, PDGF receptors can also form complexes with other tyrosine kinase receptors, such as the epidermal growth factor (EGF) receptor (Saito et al. 2001) and fibroblast growth factor (FGF) receptor-1 (Faraone et al. 2006), but also with nonkinase receptors, such as integrins (Sundberg

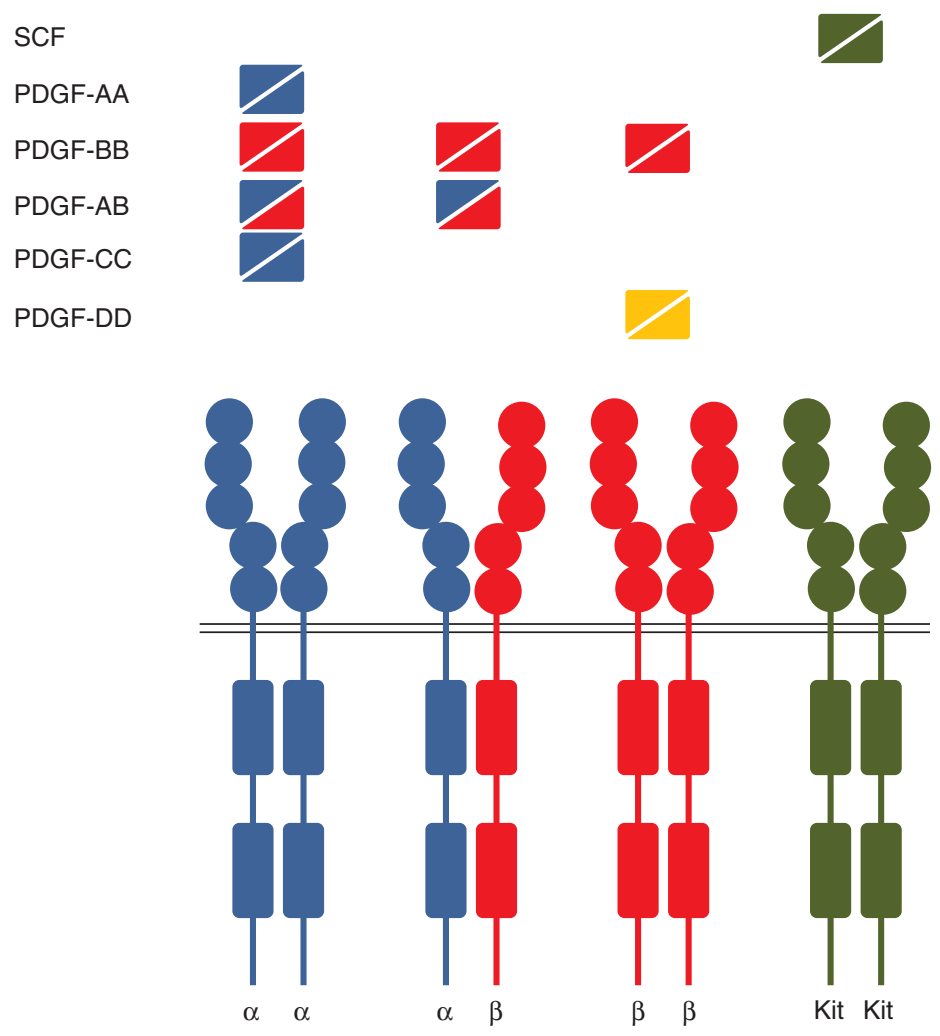

Figure 1. Ligand-binding specificities of PDGF and SCF receptors. The different ligands are depicted above the respective receptor dimers they bind to. Binding of PDGF-CC and PDGF-DD to $\alpha \beta$-heterodimeric PDGF receptors have also been described, but the functional significance of such complexes remains to be determined. 
and Rubin 1996; Schneller et al. 1997), CD44 (Li et al. 2006), the low-density lipoprotein receptor-related protein (LRP) (Boucher et al. 2002; Loukinova et al. 2002), and the poliovirus receptor Necl-5 (Minami et al. 2010). Such interactions modulate signaling via PDGF receptors.

\section{Activation of PDGF Receptor Kinases}

PDGF-induced receptor dimerization leads to autophosphorylation of certain tyrosine residues in the intracellular parts of the receptors. Thus, the $\alpha$ and $\beta$ receptors have 10 and 11 autophosphorylation sites, respectively (Fig. 2) (Heldin et al. 1998). The autophosphorylation serves two important functions: It leads to changes in the conformation of the intracellular parts of the receptors promoting their activation, and it provides docking sites for SH2-domain-containing signal transduction molecules.

There are at least three mechanisms involved in activation of PDGF receptor kinases.
Like most tyrosine kinase receptors (Hubbard 1997), the PDGF receptors are autophosphorylated in the activation loop of the kinases (residues Tyr849 and Tyr857 in the $\alpha$ and $\beta$ receptors, respectively). Phosphorylation of this residue of the $\beta$ receptor has been shown to be necessary for full activation of the receptor kinase (Baxter et al. 1998). Probably phosphorylation causes a change in conformation of the activation loop, which opens up the active site of the kinase and allows access of ATP and protein substrate. Moreover, truncation of the carboxy-terminal tail of the $\beta$ receptor causes receptor activation (Chiara et al. 2004). This suggests that the carboxyl terminus in the resting state is folded over the kinase domain keeping the kinase inactive; autophosphorylation in the carboxyl terminus is likely to relieve the inhibition. Finally, in the resting state, the juxtamembrane domain of several tyrosine kinase receptors has been shown by X-ray crystallography to be folded over and inhibit the kinase domain; autophosphorylation causes a change in conformation, which

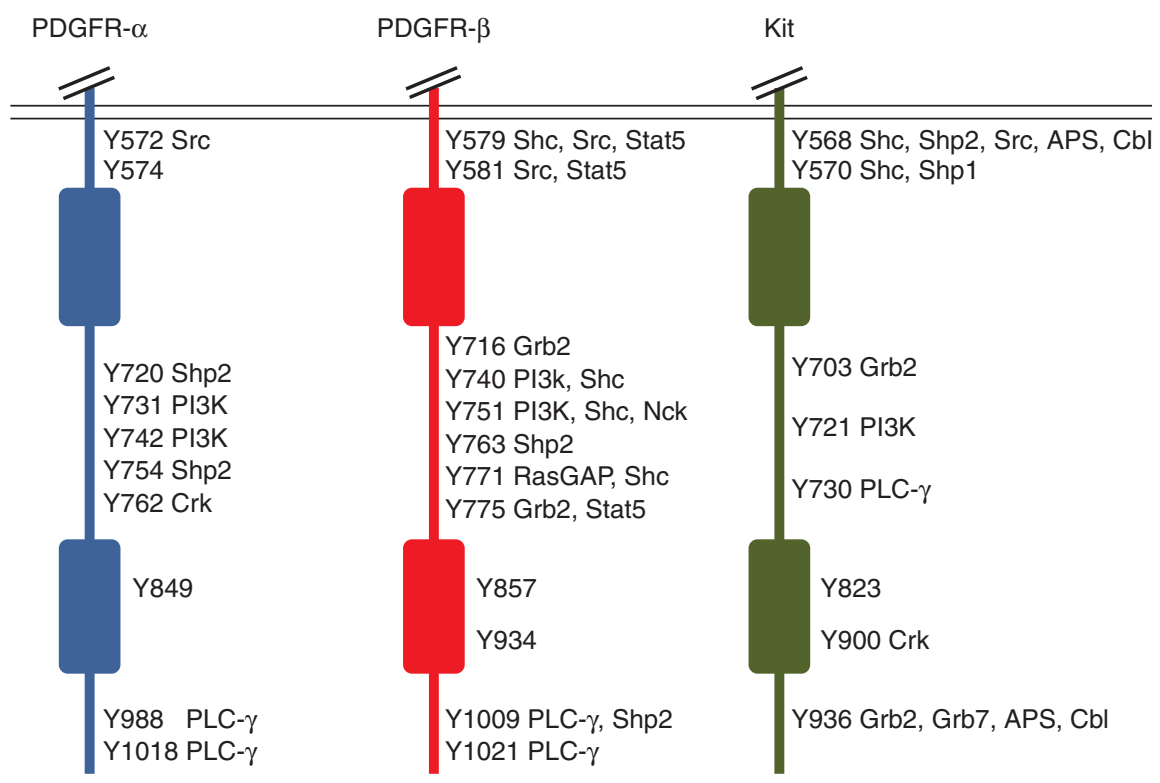

Figure 2. Binding of SH2-containing signaling molecules to phosphorylation sites in PDGF and SCF receptors. The known phosphorylated tyrosine residues and the molecules that bind to them are indicated. Y849, Y857, and Y823 in the $\alpha$ receptor, $\beta$ receptor, and Kit, respectively, are located in the activation loops of the kinase domains; no molecules are known to bind to these phosphorylation sites. Y934 and Y900 in the $\beta$ receptor and Kit, respectively, are not autophosphorylation sites, but phosphorylated by Src. 
relieves the inhibition (Wybenga-Groot et al. 2001; Hubbard 2004). A similar inhibitory function has been shown in the PDGF- $\beta$ receptor (Irusta et al. 2002). Moreover, in the context of oncogenic fusion proteins of the PDGF receptors, the juxtamembrane domains have been shown to have an inhibitory function (see further below), supporting the notion that the juxtamembrane domain has an inhibitory function also in full-length PDGF receptors. Together, these mechanisms cooperate to keep the kinase inactive; autophosphorylation of several tyrosine residues is necessary for full activation of the receptor kinase.

\section{Activation of Intracellular Signal Transduction Pathways by PDGF Receptors}

The second important function of autophosphorylation of the PDGF receptors is to allow binding of signaling molecules containing $\mathrm{SH} 2$ domains, which recognize phosphorylated tyrosine residues (Heldin et al. 1998). Because different $\mathrm{SH} 2$ domains have different preferences regarding the three to six amino acid residues downstream from the phosphorylated tyrosine, there is a certain specificity in binding. The PDGF receptors have been reported to bind about 10 different families of SH2-domain-containing molecules, which initiates the activation of different signaling pathways (Fig. 2). Because the autophosphorylation pattern of PDGF- $\alpha$ and $-\beta$ receptors differ depending on whether the receptors occur in homo- or heterodimeric complexes, each of the three dimeric PDGF receptor complexes have distinct signaling properties (Ekman et al. 1999).

Certain of the SH2-domain signaling molecules that bind to PDGF receptors have intrinsic enzymatic activities (i.e., members of the Src family of tyrosine kinases, the GTPaseactivating protein [GAP] for Ras, the tyrosine phosphatase SHP-2, and phospholipase C- $\gamma$ [PLC- $\gamma]$ ) (reviewed in Heldin and Westermark 1999). The respective enzymatic activities are activated by binding to the receptors or by phosphorylation by the receptor kinases. Alternatively, the enzymes are constitutively active and just brought to the inner leaflet of the plasma membrane by the activated receptors.

There are also examples of SH2-domaincontaining adaptor molecules, including Nck, Shc, and Crk, which bind to activated PDGF receptors. They act by mediating interactions with different downstream signaling molecules. Some of them form stable complexes with enzymes, such as Grb2, which form a complex with the nucleotide exchange molecule SOS1 activating Ras. Moreover, the $\alpha$ - or $\beta$-regulatory p 85 subunits of the phosphatidylinositol $3^{\prime}$-kinase bind to the receptors and to the $\alpha$ - or $\beta$-p110 catalytic subunits. In addition, certain members of the STAT family of transcription factors bind to and are activated by PDGF receptors (reviewed by Heldin and Westermark 1999).

The intracellular parts of the PDGF receptors also interact with certain signaling molecules independent of autophosphorylation (e.g., the PDZ-domain protein NHERF), which binds to the end of the carboxy-terminal tail of the PDGF receptors and enhances receptor signaling (Maudsley et al. 2000; Demoulin et al. 2003; Takahashi et al. 2006; Theisen et al. 2007), and the adaptor molecule Alix, which binds to the region around Tyr1021 of the carboxy-terminal tail and facilitates binding of the ubiquitin ligase Cbl (Lennartsson et al. 2006).

In order for initiation of signaling via PDGF receptors to be efficient, tyrosine phosphatases need to be inactivated (Sundaresan et al. 1995). This is achieved by a PI3-kinase-dependent oxidation of a cysteine residue in the active site of phosphatases (Bae et al. 2000).

Much effort has been put into the elucidation of which signaling pathways mediate the various effects of PDGF on cells (i.e., cell proliferation, survival, chemotaxis, and actin reorganization). Although cell-type differences have been reported, in general, PI3 kinase has been found to be important for the antiapoptotic and motility responses of PDGF. Src via activation of the transcription factor Myc, and Ras via activation of the Erk MAP kinase pathway, are important for the growth-stimulating effects. It should be noted, however, that there is an extensive cross talk between different signaling pathways. Thus, each of the many signaling pathways in- 
duced by the activated receptor can, to different extents and in a cell-type-specific manner, contribute to most of the cellular effects of PDGF.

\section{Modulation of Signaling via PDGF Receptors}

Both $\alpha \alpha$ - and $\beta \beta$-receptor complexes induce powerful mitogenic signals. However, whereas $\beta \beta$-receptor homodimers and $\alpha \beta$ heterodimers induce chemotaxis, the $\alpha \alpha$ homodimer inhibits chemotaxis, at least in certain cell types (Eriksson et al. 1992). The $\alpha \beta$-heterodimeric receptor complex appears to induce the most potent mitogenic signal. A mechanism for this difference could be that Tyr771, to which RasGAP binds, is efficiently phosphorylated in the $\beta \beta$ homodimer, but not in the $\alpha \beta$ heterodimer (Ekman et al. 1999). Thus, RasGAP, which deactivates Ras, cannot bind to the $\alpha \beta$-receptor heterodimer leading to a more efficient activation of Ras by the $\alpha \beta$-receptor heterodimer.

The simultaneous binding to activated PDGF receptors of the Grb2/SOS1 complex, which activates Ras, and of RasGAP, which inactivates Ras, provides an example of how signaling via PDGF receptors can be modulated. Another example is the binding of the tyrosine phosphatase SHP-2, which dephosphorylates the $\beta$ receptor and its substrates (Lechleider et al. 1993). However, in addition to negatively modulating PDGF receptor signaling via dephosphorylation, SHP-2 also positively contributes to signaling through dephosphorylation of the carboxy-terminal tyrosine residue in Src, whereby Src is activated, and by functioning as an adaptor, which can bind Grb2/SOS1, thus promoting activation of Ras (Dance et al. 2008).

\section{Internalization and Sorting of PDGF Receptors}

Following ligand binding, PDGF receptors are accumulated in coated pit areas at the cell membrane, and then internalized in a clathrin- and dynamin-dependent manner, in a process that partly depends on the kinase activity of the receptors (Sorkin et al. 1991). Signaling continues in endosomes (Wang et al. 2004), until the $\mathrm{pH}$ decreases enough to cause dissociation of PDGF from its receptors. Most of the internalized PDGF receptors are degraded by fusion of endosomes with multivesicular bodies and lysosomes, or by degradation in proteasomes, processes that are promoted by polyubiquitination of the receptors (Heldin et al. 1982; Mori et al. 1992). Ubiquitination of the PDGF- $\beta$ receptor can be performed by the ubiquitin ligase $\mathrm{Cbl}$ (Miyake et al. 1999); degradation of Cbl is promoted by the adaptor molecule Alix, which binds to the PDGF- $\beta$ receptor, thereby preventing ubiquitination of the receptor and thus stabilizing it (Lennartsson et al. 2006).

Although most of PDGF receptors are degraded after ligand-induced internalization, there are mechanisms that affect sorting and promote recycling of the receptor to the plasma membrane. One such mechanism was shown to involve overactivation of PLC- $\gamma$ and its downstream effectors PKC $\alpha$ in cells deficient of the tyrosine phosphatase TC-PTP (Karlsson et al. 2006); TC-PTP dephosphorylates preferentially Tyr1021 in the PDGF- $\beta$ receptor, which is the binding site of PLC- $\gamma$. The overactivated PLC$\gamma$ was found to promote recycling in a protein kinase C-dependent manner (Hellberg et al. 2009). Another mechanism was found to operate in Ras-transformed fibroblasts; in these cells, PI3-kinase is overactivated leading to internalization of receptors via macropinocytosis, which is accompanied by increased recycling (Schmees et al. 2012). In both these cases, the induction of recycling was associated with an increased PDGF signal strength and duration. Thus, modulation of intracellular sorting mechanisms can affect PDGF signaling.

\section{Function of PDGF and PDGF Receptors during Embryonal Development}

Primarily based on gene knockout studies in mice, PDGF and PDGF receptors have been shown to have important roles to promote proliferation, migration, and differentiation of specific cell types during the embryonal development (reviewed by Andrae et al. 2008). A common theme that has emerged from these studies is that PDGF isoforms, secreted by epithelial or endothelial cells, act in a paracrine 
manner on nearby mesenchymal cells, such as fibroblasts, pericytes, and smooth muscle cells (Hoch and Soriano 2003; Andrae et al. 2008).

Knockout of PDGFR- $\alpha$ and PDGF-A was found to affect early mesenchymal derivatives in both embryo and extraembryo tissues, and a proportion of these mice die before or at embryonic day 10.5 (Hoch and Soriano 2003). Knockout of PDGFR- $\alpha$ also causes defects in neural crest mesenchyme derivatives, including the cardiac outflow tract, the thymus and skeletal components in the facial and other regions, and in the development of the palate and teeth (Soriano 1997; Tallquist et al. 2000; Tallquist and Soriano 2003; Xu et al. 2005).

PDGF-A knockout mice that survive birth develop lung emphysema, because PDGFR- $\alpha$ positive alveolar myofibroblast precursors do not migrate to the alveolar saccules (Boström et al. 1996; Lindahl et al. 1997b). Knockout of PDGF-A or PDGFR- $\alpha$ in mice also leads to abnormal development of gastrointestinal villi (Karlsson et al. 2000), skin blistering (Soriano 1997), reduced hair development (Karlsson et al. 1999), and defect development of Leydig cells of the testis (Gnessi et al. 2000; Brennan et al. 2003). In each case, the interaction between the PDGFR- $\alpha$ expressed by mesenchymal cells of different kinds, and the ligand expressed by neighboring epithelial cells, is perturbed.

PDGFR- $\alpha$ also mediates signals needed for proliferation and differentiation of oligodendrocyte progenitor cells (Calver et al. 1998) and retinal astrocytes (Fruttiger et al. 1996), and determines the number of oligodendrocyte progenitor cells in the adult brain (Woodruff et al. 2004). PDGF-AA is constitutively secreted from neuronal cell bodies but not from axons (Fruttiger et al. 2000).

PDGFR- $\beta$ is expressed on pericytes and vascular smooth muscle cells and mediates recruitment of these cells to newly formed vessels in response to PDGF-BB secreted by endothelial cells (Lindahl et al. 1997a; Hellström et al. 1999; Bjarnegård et al. 2004), and in particular by the tip cells that lead the angiogenic sprout (Gerhardt et al. 2003). PDGFR- $\beta$ knockout embryos progressively develop abnormal glomeruli in the kidney owing to defect development of mesangial cells (Levéen et al. 1994; Soriano 1994; Lindahl et al. 1998), capillary microaneurysm (Lindahl et al. 1997a), cardiac defects (Van den Akker et al. 2008), and placental defects (Ohlsson et al. 1999), and die at E16-E19 from hemorrhage. A role for PDGFR- $\beta$ in the early development of hematopoietic/endothelial precursors has also been shown; activation of PDGFR- $\beta$ on these cells drives differentiation toward endothelial cells (Rolny et al. 2006).

It is thus clear that PDGFR- $\alpha$ and PDGFR$\beta$ have different functions during embryonal development. To determine whether the differences are owing to different expression patterns or to different signaling capacities, the intracellular parts of the receptors were swapped (Klinghoffer et al. 2001). Whereas loss of the cytoplasmic part of PDGFR- $\alpha$ could be rescued by the cytoplasmic part of PDGFR- $\beta$, loss of the intracellular part of PDGFR- $\beta$ was only partly rescued by the intracellular part of PDGFR$\alpha$. A partial rescue was also obtained when the PDGFR- $\alpha$ kinase domain was replaced with a more distant kinase domain (Hamilton et al. 2003). These findings suggest that both expression patterns and signaling capacities account for the differences in function of the two PDGF receptors (Klinghoffer et al. 2001).

\section{Function of PDGF and PDGF Receptors in the Adult}

In the adult, activation of PDGFR- $\beta$ controls the intestinal fluid pressure of tissues and prevents formation of edema (Rodt et al. 1996). A probable mechanism is that fibroblasts and myofibroblasts, which express PDGFR- $\beta$, make contact with extracellular components via their integrins; activation of PDGFR- $\beta$ induces contraction of the cells, which controls the interstitial fluid pressure (Lidén et al. 2006).

PDGF has also been shown to stimulate wound healing (Robson et al. 1992). PDGF receptors are expressed by several cell types involved in wound healing, such as fibroblasts, smooth muscle cells, neutrophils, and macrophages; on PDGF stimulation these cells are recruited to the wounded area (e.g., by PDGF released from platelets). PDGF also contributes 
to wound healing by stimulating the production of different matrix molecules (reviewed by Heldin and Westermark 1999).

A specific function for PDGFR- $\alpha$ to promote proliferation of insulin-promoting $\beta$ cells in juvenile pancreatic islets was recently elucidated (Chen et al. 2011).

\section{Role of PDGF Receptor Activation in Diseases}

PDGF receptor activation has been observed in cancer and in other diseases involving excess cell proliferation, such as atherosclerosis and fibrotic conditions.

\section{Overactivity of PDGF Receptors in Tumor Cells}

Certain malignancies are characterized by mutations in PDGF receptor genes. Thus, 5\% of gastrointestinal stromal tumors (GIST) show point mutations in the PDGFR- $\alpha$ gene (Heinrich et al. 2003); in this tumor type, mutations in the Kit gene are even more common (see below). The mutations affect the control mechanisms involved in keeping the receptor kinase inactive and lead to a constitutively active kinase. Similar activating point mutations in PDGFR- $\alpha$ have also been observed in hypereosinophilic syndrome (Elling et al. 2011).

In chronic myelomonocytic leukemia (CMML) the intracellular part of the PDGFR$\beta$ gene has been found to be fused to the TEL gene (Golub et al. 1994) or other genes that have in common that they encode proteins that can dimerize or oligomerize (Magnusson et al. 2001). Similarly, the PDGFR- $\alpha$ gene is fused to the FIP1L1 gene in hypereosinophilic syndrome (Cools et al. 2003; Griffin et al. 2003) and in systemic mastocytosis (Pardanani et al. 2003). The resulting fusion proteins have constitutively active kinases as a result of juxtaposition of the kinases of the receptors, as well as by the loss of regulatory sequences in the juxtamembrane (Stover et al. 2006) and transmembrane (Toffalini et al. 2010) domains.

The PDGFR- $\alpha$ gene has been found to be amplified in subsets of glioblastomas (Fleming et al. 1992; Kumabe et al. 1992; Puputti et al. 2006), anaplastic oligodendrogliomas (Smith et al. 2000), esophageal squamous cell carcinoma (Arai et al. 2003), and pulmonary artery intimal sarcoma (Zhao et al. 2002). The increased number of receptors on such cells makes the cells very sensitive to PDGF stimulation; moreover, at a sufficiently high receptor density, ligandindependent activation may occur. In addition, an activated deletion mutant of PDGFR- $\alpha$ has been found in a human glioblastoma (Clarke and Dirks 2003).

PDGF receptors may be activated also as a consequence of mutation of ligand genes. Thus, in the rare skin tumor dermatofibrosarcoma protuberans (DFSP), the PDGF-B gene is fused to the collagen 1A1 gene (Simon et al. 1997; O'Brien et al. 1998), resulting in the production of large amounts of a fusion protein, which after processing becomes similar to mature PDGF$\mathrm{BB}$ that activates its receptors in an autocrine manner (Shimizu et al. 1999).

Epithelial tumors can undergo epithelialmesenchymal transition (EMT), whereby they lose their epithelial characteristics and start to express mesenchymal components, such as PDGF receptors (Thiery et al. 2009). Thus, whereas epithelial tumors generally do not respond to PDGF, they may do so after they have undergone EMT (Jechlinger et al. 2003). EMT correlates with increased invasiveness and metastasis; interestingly, inhibition of PDGF signaling was shown to inhibit metastasis in mouse models for breast cancer (Jechlinger et al. 2006), hepatocellular carcinoma (Gotzmann et al. 2006), and prostate cancer (Dolloff et al. 2005; Russell et al. 2009). PDGFR- $\alpha$ appears to be more important than PDGFR- $\beta$ in the promotion of metastasis of epithelial tumors.

A malignancy-dependent increase in expression of PDGF isoforms and receptors has been observed in glioblastoma tumors. Thus, in this tumor type, PDGF appears to be involved in autocrine and paracrine stimulation, both in the tumor cells via PDGFR- $\alpha$ and in cells of the stroma via PDGFR- $\beta$ (Hermanson et al. 1992). Moreover, in basal cell carcinoma, activation of the sonic hedgehog signaling pathway induces the expression of PDGFR- $\alpha$ (Xie et al. 2001). 


\section{Activation of PDGF Receptors in the Stromal Compartment of Tumors}

In addition to direct effects on the tumor cells, PDGF made by tumor cells and other cell types in solid tumors acts in a paracrine manner on various cell types in the vasculature and in the interstitial stroma of tumors (Pietras et al. 2008). Thus, PDGF promotes tumor angiogenesis by stimulating perivascular progenitor cells, pericytes, and vascular smooth muscle cells (Song et al. 2005), and by recruiting protumorigenic inflammatory cells. Moreover, overactivity of PDGF contributes to the increased interstitial fluid pressure that characterizes a majority of solid tumors, which leads to a decreased transcapillary transport and is therefore an obstacle in the treatment of tumors with chemotherapeutical drugs (Heldin et al. 2004).

\section{Activation of PDGF Receptors in Atherosclerosis}

PDGF isoforms and receptors occur at increased levels in atherosclerotic lesions. According to the response to injury hypothesis, PDGF isoforms released by platelets at sites of endothelial cell injury stimulate vascular smooth muscle cells to migrate from the vessel media into the intima and to proliferate (Ross 1993). Chronic inflammation involving release of PDGF from different types of immune cells also contributes to the narrowing of the vessel lumen (Hansson 2005). PDGF and other growth factors and cytokines released then maintain the local inflammation in a vicious circle.

\section{Activation of PDGF Receptors in Fibrotic Diseases}

Increased PDGF signaling has also been linked to various fibrotic conditions, such as lung fibrosis, myelofibrosis, glomerulonephritis, and liver cirrhosis. During chronic inflammation, activated macrophages secrete PDGF isoforms as well as other inflammatory cytokines, which up-regulate PDGF receptors on mesenchymal cells, thus promoting their proliferation and production of matrix molecules (Bonner 2004). In support of the notion that overactive PDGF signaling drives fibrosis, knockin of constitutively active mutants of PDGFR- $\alpha$ was found to lead to increased connective tissue growth and a progressive fibrotic phenotype in multiple organs (Olson and Soriano 2009). Knockin of a similar PDGFR- $\beta$ mutant caused an enhanced wound healing response in the skin and the liver (Krampert et al. 2008).

\section{PDGF Receptors as Binders of Viruses}

PDGFR- $\alpha$ has been shown to be a receptor for adeno-associated virus type 5 (Di Pasquale et al. 2003) and cytomegalovirus (Soroceanu et al. 2008). Thus, PDGFR- $\alpha$ facilitates infections by these viruses.

\section{DEVELOPMENT AND CLINICAL USE OF PDGF ANTAGONISTS}

Because overactivity of PDGF signaling is connected to many serious diseases, efforts have been made to develop antagonists of PDGF signaling. Several types of inhibitors are now available, including DNA aptamers binding PDGF isoforms, inhibitory antibodies against the receptors, and low molecular weight inhibitors of PDGF receptor kinases (e.g., imatinib, sunitinib, and sorafenib) (Demetri 2011). Beneficial effects have been observed by treatment of the rare malignancies that are driven by mutations in genes for PDGF and PDGF receptors (i.e., CMML, DFSP, hypereosinophilic syndrome, and GIST). However, treatment of glioblastoma that also often is characterized by overactivity of PDGF receptors, with PDGF antagonists, has been less successful; probably these tumors have undergone too many other genetic or epigenetic alterations and inhibition of PDGF receptor signaling is therefore not enough. There are indications that anti-PDGF treatment could be of more general application for the targeting of the stroma compartment of solid tumors, to inhibit metastasis (Pietras et al. 2003; Catena et al. 2010), and to lower the interstitial fluid pressure and thereby increase the transcapillary flow and drug delivery (Heldin et al. 2004). The side effects of anti-PDGF therapy have been relatively mild, but include a tendency to develop 
edema, reflecting the important role of PDGF in regulation of the interstitial fluid pressure (Rodt et al. 1996), and heart failure, reflecting an important role of PDGF in stress-induced cardiac angiogenesis (Chintalgattu et al. 2010). In patients with advanced ovarian cancer, treatment with the inhibitory Fab fragment CDP860 led to the development of significant ascites (Jayson et al. 2005).

\section{STEM CELL FACTOR RECEPTOR (Kit)}

\section{Activation of Kit by SCF}

The biologically active SCF is a homodimeric protein that is primarily produced by fibroblasts and endothelial cells, and exists both as a soluble and membrane-bound form owing to alternative splicing of exon 6 (Huang et al. 1992). Both forms of SCF are initially produced as transmembrane proteins, but the protein containing exon 6 becomes cleaved into the soluble SCF and the form lacking this exon remains membrane associated. Several proteases have been suggested to be involved in the processing of SCF, including MMP9, members of the ADAM family, and Chymase-1 (Longley et al. 1997; Heissig et al. 2002; Kawaguchi et al. 2007).

The SCF receptor is also called Kit, because it was first identified as an oncoprotein derived from the Hardy-Zuckerman 4 feline sarcoma virus (Besmer et al. 1986). It is expressed in primitive hematopoietic cells and mast cells, but also in melanocytes and basal cells in the skin, germs cells, interstitial cells of Cajal, and in certain regions of the brain. There are four human isoforms of Kit. Two splice forms are characterized by the presence or absence of a four-amino-acid sequence in the extracellular juxtamembrane region (Reith et al. 1991). These two splice forms display different signaling abilities with the shorter form being more strongly tyrosine phosphorylated and more powerful in activation of downstream signaling, whereas the longer Kit splice form signals less intensely but more persistently (Caruana et al. 1999; Voytyuk et al. 2003). Kit isoforms are also characterized by the absence or presence of a serine residue in the kinase insert region (Crosier et al. 1993).
The process by which SCF activates Kit has been studied both at a biochemical and structural level, and occurs in a manner similar to that described above for the PDGF receptor; the dimeric SCF ligand brings two Kit monomers in close proximity of each other, which enables interactions between the extracellular domains of the receptors generating a stable dimer (Fig. 1) (Lemmon et al. 1997; Zhang et al. 2000; Yuzawa et al. 2007).

The crystal structure of the Kit kinase domain revealed that the juxtamembrane region is inserted between the two lobes of the kinase domain thereby suppressing kinase activity, and that this inhibition is released on phosphorylation of tyrosine residues within the juxtamembrane segment (Mol et al. 2003, 2004). A kinetic study of the autophosphorylation process showed that the juxtamembrane region is first to be phosphorylated, consistent with the role of this region in suppressing the kinase activity (DiNitto et al. 2010).

\section{Activation of Intracellular Pathways by Kit}

The intracellular region of Kit contains seven autophosphorylation sites that are involved in the activation of the Kit kinase and can act as docking sites for intracellular signaling proteins (Fig. 2). The signaling pathways activated downstream from Kit overlap to a large extent with those described for the PDGF receptor (see above), and include PI3-kinase, Src kinases, MAP kinase pathways, and phospholipase C and D. Furthermore, it is well established that there exists a comprehensive cross talk between different pathways. For example, Src kinases contribute to Erk1/2 activation, and Src in combination with PI3-kinase promotes Jnk activation, in response to SCF (Timokhina et al. 1998; Lennartsson et al. 1999).

Attempts to study the role of individual signaling proteins include mutation of all tyrosine residues in the intracellular region of Kit and then adding them back one at a time. Using this approach, it was found that the Src docking site on Kit is important for the migratory, survival, and, partially, the proliferative response to SCF, whereas restoring coupling to PI3-kinase 
only had a small effect on the survival and migration of cells (Hong et al. 2004). In addition, by mutating individual tyrosine residues in Kit, it was found that Src and PI3-kinase binding are essential for cell migration (Ueda et al. 2002). These studies identify Src and PI3-kinase signaling as especially important in SCF-induced responses in vitro. Also, in vivo studies have confirmed the role of the Src and PI3-kinase in Kit-mediated functions. Mice expressing Kit lacking the Src binding site display primarily defects in the immune system, whereas lack of the PI3-kinase binding site generated fertility deficiencies (Blume-Jensen et al. 2000; Kissel et al. 2000; Agosti et al. 2004; Kimura et al. 2004).

The absence of clear functions of the other autophosphorylation sites in Kit probably reflects redundancy masking the role of binding of signaling proteins to these sites. Furthermore, the role of individual signaling pathways may vary between different cell types illustrated by the specific defects described above in mice expressing different Kit mutations, in which some tissues are strongly affected, whereas others are not, although they all express the same Kit mutant.

\section{Down-Regulation of Kit}

There are several mechanisms that act in parallel to down-regulate Kit signaling ensuring an appropriate signal intensity and duration. These include Kit ubiquitination and internalization, dephosphorylation, and PKC-dependent serine phosphorylation. Because all these processes require Kit activation for their initiation they function as negative-feedback loops limiting the signaling output from the receptor once it has been activated.

As described above for PDGF receptors, the activated Kit is internalized through clathrincoated pits. Ubiquitination of Kit, which occurs in concert with the internalization process, depends on the ubiquitin ligase $\mathrm{Cbl}$ that can bind either directly to Kit or indirectly through adaptor proteins, such as Grb2, p85, or CrkL (Wisniewski et al. 1996; Sattler et al. 1997; Masson et al. 2006). In addition, a SOCS6-containing ubiquitination complex has been found to in- teract with Kit and promote its down-regulation (Bayle et al. 2004; Zadjali et al. 2011). The internalized Kit is sorted inside the cell toward degradation, which occurs in both lysosomes and proteasomes (Miyazawa et al. 1994; Zeng et al. 2005).

The activity of many kinases is suppressed by the action of phosphatases. In the case of Kit, the phosphatase SHP1 has been shown to associate and negatively regulate the activated Kit (Paulson et al. 1996; Kozlowski et al. 1998).

Protein kinase $\mathrm{C}(\mathrm{PKC})$ is activated downstream from Kit and phosphorylates Kit on serine residues in the kinase insert region, which leads to reduced Kit kinase activity (Blume-Jensen et al. 1993, 1995). Moreover, activation of PKC also results in shedding of the extracellular domain of Kit limiting the ability of SCF to stimulate cells (Yee et al. 1994).

\section{Function of Kit}

There are a large number of mouse loss-of-function mutations both in the Kit ( $W$ loci) and SCF ( $S l$ loci) genes with varying degrees of severity. From the study of these mutant mice it was found that hematopoiesis, pigmentation, fertility, peristaltic movement, and certain aspects of the nervous system, are regulated by Kit signaling.

\section{Hematopoiesis}

Kit has been found to be expressed in primitive hematopoietic cells but the expression declines during differentiation, except for mast cells that retain high Kit expression also as fully differentiated cells (Ogawa et al. 1991; Oliveira and Lukacs 2003). Kit promotes cell survival and proliferation of primitive hematopoietic cells, often in synergy with other cytokines.

\section{Pigmentation}

Kit is expressed on melanocytes and has been found to be important for the migration of these cells from the neuronal crest to the dermis during development (Wehrle-Haller 2003). Defects in Kit signaling interferes with melanocyte mi- 
gration and gives rise to the pigmentation defects found in patients with piebaldism (see below).

\section{Fertility}

The reduced fertility of $W$ and $S l$ mutant mice was confirmed by knockin experiments with a Kit mutant unable to activate PI3-kinase; this resulted in sterile mice or mice with reduced fertility depending on gender (Blume-Jensen et al. 2000; Kissel et al. 2000). Because Kit signaling through PI3-kinase has been found to be important for survival (Blume-Jensen et al. 1998), a likely reason for the reduced fertility is an inability of mutant Kit to support viability of germ cells. A truncated cytoplasmic form of Kit (tr-Kit) exists in sperm owing to usage of an alternative promoter (Rossi et al. 2003). Tr-Kit has been found to be important for activation of the oocyte after fertilization (Sette et al. 1997).

\section{Peristaltic Movement}

Interstitial cells of Cajal (ICC) function as pacemaker cells and can communicate with both smooth muscle cells and nerves. It was found that $W$ and $S l$ mice have a constipation phenotype, which is correlated with a reduced number of ICC (Huizinga et al. 1995; Ward et al. 1995). Also, in humans, a loss of ICC has been associated with defective gut movement and constipation (Lyford et al. 2002).

\section{Nervous System}

Kit expression has been found in neurons and $W$ and $S l$ mutant mice have defects in spatial learning (Motro et al. 1996; Katafuchi et al. 2000). Furthermore, neuroproliferative zones in adult rat have been found to be positive for Kit (Jin et al. 2002).

\section{Role of Kit in Diseases}

\section{Acute Myeloid Leukemia}

Acute myeloid leukemia (AML) is characterized by an uncontrolled increase in the number of cells from the myeloid lineage that accumulate in the bone marrow and interfere with normal hematopoiesis. Kit expression is found in $60 \%-$ $80 \%$ of AML cells and treatment with SCF results in increased cell proliferation (Ikeda et al. 1991; Odenike et al. 2011). Furthermore, activating mutations in Kit have been found in AML patients, although not very frequently (Odenike et al. 2011).

\section{GIST}

GISTs derive from ICC, which are pacemaker cells for peristaltic movement (Wang et al. 2000). These tumors are frequently driven by mutations in Kit, or PDGFR- $\alpha$, often located in the juxtamembrane region, although mutations in the kinase domain and extracellular region have also been found (Antonescu 2011).

\section{Mastocytosis}

Mastocytosis is a disease characterized by abnormal accumulation of mast cells in tissues. Mast cells are among the few differentiated hematopoietic cells that retain Kit expression and patients with mastocytosis frequently harbor activating mutations within the kinase domain (Ustun et al. 2011).

\section{Melanoma}

Melanoma is a malignant disease of melanocytes, which can be located in different parts of the body, although most frequently in the skin. Normally, melanocytes express Kit, but the role of this receptor in melanoma is complicated; Kit has been found to be down-regulated in cutaneous melanoma (Easty and Bennett 2000), but activating mutations have been reported in other types of melanoma (Curtin et al. 2006; Ashida et al. 2009).

\section{Small-Cell Lung Cancer}

Small-cell lung cancer (SCLC) is an aggressive form of lung cancer that is often associated with smoking (Jackman and Johnson 2005). It was shown that SCLC cells coexpress Kit and SCF 
suggesting the presence of an autocrine loop (Hibi et al. 1991). However, immunohistochemical staining of tumors for Kit expression yielded varying results both regarding Kit expression and correlation with clinical outcome (Fischer et al. 2007). Furthermore, no activating Kit mutations could be found in SCLC tumors. Although imatinib inhibits growth of SCLC cell lines, it failed to show efficiency in animal models (Wolff et al. 2004). However, combining imatinib with chemotherapy (Decaudin et al. 2005), or using SU5416, which inhibits several kinases including Kit, produced more positive results in experimental models (Litz et al. 2004).

\section{Piebaldism}

In cancer, Kit is activated by gain-of-function mutations or by autocrine stimulation. In contrast, piebaldism involves germline loss-offunction mutations in Kit leading to patches of skin and hair that are depigmented owing to lack of melanocytes (Spritz 1994).

\section{Clinically Used Kit Antagonists}

Overactivity of Kit has been found in several malignant diseases (see above) and inhibiting Kit kinase activity is an approach to treat these conditions. Imatinib, also discussed in the PDGF receptor context above, inhibits Kit and has been used clinically. Because imatinib does not efficiently inhibit Kit with activating mutations within the kinase domain (Frost et al. 2002; Ma et al. 2002), other drugs have been developed that can inhibit Kit with such mutations, such as dasatinib and nilotinib (Demetri 2011). Thus, depending on the mutational status of Kit, different drugs should be selected. Neither of the drugs mentioned above exclusively inhibit Kit, but inhibit also other kinases and this may contribute to their clinical effectiveness. Other multiselective drugs whose targets include Kit are sunitinib and sorafenib. Masitinib is a potent inhibitor that targets Kit among other kinases and is approved for treating mast cell tumors in a veterinary setting.

\section{FUTURE PERSPECTIVE}

Studies over the last 30 years have revealed much about the structural properties, signaling capacities, normal functions, and role in diseases of PDGF and SCF receptors. Moreover, treatment regimens for malignant diseases in which these receptors are overactive are used routinely in the clinic. Future studies will aim at elucidating mechanisms for control of receptor signaling, including internalization, intracellular sorting, and termination of signaling. It is anticipated that such control mechanisms will include posttranslational modifications of the receptors and their signaling mediators, other than the already characterized phosphorylation and ubiquitination. Additional information is also needed regarding cooperation of the receptors with coreceptors at the cell membrane, as well as the importance of interactions with the receptors and intracellular molecules, to enhance or control their signaling capacities. It will also be important to determine exactly where in the cell the receptors induce their different signals: at the plasma membrane, in endosomes, or in other intracellular organelles. In addition, whereas some information is available regarding the involvement of PDGF and SCF receptors in disease, a more detailed analysis of these receptors in malignant as well as nonmalignant diseases is highly warranted, as are more efficient and specific methods to treat diseases in which the receptors are overactive.

\section{ACKNOWLEDGMENT}

We thank Ingegärd Schiller for valuable help in the preparation of this manuscript.

\section{REFERENCES}

Agosti V, Corbacioglu S, Ehlers I, Waskow C, Sommer G, Berrozpe G, Kissel H, Tucker CM, Manova K, Moore MA, et al. 2004. Critical role for Kit-mediated Src kinase but not PI 3-kinase signaling in pro T and pro B cell development. J Exp Med 199: 867-878.

Andrae J, Gallini R, Betsholtz C. 2008. Role of platelet-derived growth factors in physiology and medicine. Genes Dev 22: 1276-1312.

Antonescu CR. 2011. The GIST paradigm: Lessons for other kinase-driven cancers. J Pathol 223: 251-261. 
Arai H, Ueno T, Tangoku A, Yoshino S, Abe T, Kawauchi S, Oga A, Furuya T, Oka M, Sasaki K. 2003. Detection of amplified oncogenes by genome DNA microarrays in human primary esophageal squamous cell carcinoma: Comparison with conventional comparative genomic hybridization analysis. Cancer Genet Cytogenet 146: 16-21.

Ashida A, Takata M, Murata H, Kido K, Saida T. 2009. Pathological activation of KIT in metastatic tumors of acral and mucosal melanomas. Int J Cancer 124: 862-868.

Bae YS, Sung J-Y, Kim O-S, Kim YJ, Hur KC, Kazlauskas A, Rhee SG. 2000. Platelet-derived growth factor-induced $\mathrm{H}_{2} \mathrm{O}_{2}$ production requires the activation of phosphatidylinositol 3-kinase. J Biol Chem 275: 10527-10531.

Ball SG, Shuttleworth CA, Kielty CM. 2007. Vascular endothelial growth factor can signal through platelet-derived growth factor receptors. J Cell Biol 177: 489-500.

Baxter RM, Secrist JP, Vaillancourt RR, Kazlauskas A. 1998. Full activation of the platelet-derived growth factor $\beta$ receptor kinase involves multiple events. J Biol Chem 273: $17050-17055$.

Bayle J, Letard S, Frank R, Dubreuil P, De Sepulveda P. 2004. Suppressor of cytokine signaling 6 associates with KIT and regulates KIT receptor signaling. J Biol Chem 279: 12249-12259.

Besmer P, Murphy JE, George PC, Qiu FH, Bergold PJ, Lederman L, Snyder HW Jr, Brodeur D, Zuckerman EE, Hardy WD. 1986. A new acute transforming feline retrovirus and relationship of its oncogene v-kit with the protein kinase gene family. Nature 320: 415-421.

Bjarnegård M, Enge M, Norlin J, Gustafsdottir S, Fredriksson S, Abramsson A, Takemoto M, Gustafsson E, Fässler R, Betsholtz C. 2004. Endothelium-specific ablation of PDGFB leads to pericyte loss and glomerular, cardiac and placental abnormalities. Development 131: 1847-1857.

Blume-Jensen P, Hunter T. 2001. Oncogenic kinase signalling. Nature 411: 355-365.

Blume-Jensen P, Siegbahn A, Stabel S, Heldin C-H, Rönnstrand L. 1993. Increased Kit/SCF receptor induced mitogenicity but abolished cell motility after inhibition of protein kinase C. EMBO J 12: 4199-4209.

Blume-Jensen P, Wernstedt C, Heldin C-H, Rönnstrand L. 1995. Identification of the major phosphorylation sites for protein kinase $\mathrm{C}$ in Kit/stem cell factor receptor in vitro and in intact cells. J Biol Chem 270: 14192-14200.

Blume-Jensen P, Janknecht R, Hunter T. 1998. The Kit receptor promotes cell survival via activation of PI 3-kinase and subsequent Akt-mediated phosphorylation of Bad on Ser136. Curr Biol 8: 779-782.

Blume-Jensen P, Jiang G, Hyman R, Lee KF, O'Gorman S, Hunter T. 2000. Kit/stem cell factor receptor-induced activation of phosphatidylinositol $3^{\prime}$-kinase is essential for male fertility. Nat Genet 24: 157-162.

Bonner JC. 2004. Regulation of PDGF and its receptors in fibrotic diseases. Cytokine Growth Factor Rev 15: 255273.

Boström H, Willetts K, Pekny M, Levéen P, Lindahl P, Hedstrand $H$, Pekna M, Hellström M, Gebre-Medhin S, Schalling M, et al. 1996. PDGF-A signaling is a critical event in lung alveolar myofibroblast development and alveogenesis. Cell 85: 863-873.
Boucher P, Liu P, Gotthardt M, Hiesberger T, Anderson RG, Herz J. 2002. Platelet-derived growth factor mediates tyrosine phosphorylation of the cytoplasmic domain of the low density lipoprotein receptor-related protein in caveolae. J Biol Chem 277: 15507-15513.

Brennan J, Tilmann C, Capel B. 2003. PDGFR- $\alpha$ mediates testis cord organization and fetal Leydig cell development in the XY gonad. Genes Dev 17: 800-810.

Calver AR, Hall AC, Yu WP, Walsh FS, Heath JK, Betsholtz C, Richardson WD. 1998. Oligodendrocyte population dynamics and the role of PDGF in vivo. Neuron 20: 869882.

Caruana G, Cambareri AC, Ashman LK. 1999. Isoforms of c-KIT differ in activation of signalling pathways and transformation of NIH3T3 fibroblasts. Oncogene 18: 5573-5581.

Catena R, Luis-Ravelo D, Anton I, Zandueta C, Salazar-Colocho P, Larzabal L, Calvo A, Lecanda F. 2010. PDGFR signaling blockade in marrow stroma impairs lung cancer bone metastasis. Cancer Res 71: 164-174.

Chen H, Gu X, Liu Y, Wang J, Wirt SE, Bottino R, Schorle H, Sage J, Kim SK. 2011. PDGF signalling controls age-dependent proliferation in pancreatic $\beta$-cells. Nature 478: $349-355$.

Chiara F, Bishayee S, Heldin C-H, Demoulin J-B. 2004. Autoinhibition of the platelet-derived growth factor $\beta$ receptor tyrosine kinase by its C-terminal tail. J Biol Chem 279: 19732-19738.

Chintalgattu V, Ai D, Langley RR, Zhang J, Bankson JA, Shih TL, Reddy AK, Coombes KR, Daher IN, Pati S, et al. 2010. Cardiomyocyte PDGFR- $\beta$ signaling is an essential component of the mouse cardiac response to load-induced stress. J Clin Invest 120: 472-484.

Clarke ID, Dirks PB. 2003. A human brain tumor-derived PDGFR- $\alpha$ deletion mutant is transforming. Oncogene 22: $722-733$.

Cools J, DeAngelo DJ, Gotlib J, Stover EH, Legare RD, Cortes J, Kutok J, Clark J, Galinsky I, Griffin JD, et al. 2003. A tyrosine kinase created by fusion of the PDGFRA and FIP1L1 genes as a therapeutic target of imatinib in idiopathic hypereosinophilic syndrome. N Engl J Med 348: 1201-1214.

Crosier PS, Ricciardi ST, Hall LR, Vitas MR, Clark SC, Crosier KE. 1993. Expression of isoforms of the human receptor tyrosine kinase c-kit in leukemic cell lines and acute myeloid leukemia. Blood 82: 1151-1158.

Curtin JA, Busam K, Pinkel D, Bastian BC. 2006. Somatic activation of KIT in distinct subtypes of melanoma. JClin Oncol 24: 4340-4346.

Dance M, Montagner A, Salles JP, Yart A, Raynal P. 2008. The molecular functions of Shp2 in the Ras/Mitogenactivated protein kinase (ERK1/2) pathway. Cell Signal 20: $453-459$.

Decaudin D, de Cremoux P, Sastre X, Judde JG, Nemati F, Tran-Perennou C, Freneaux P, Livartowski A, Pouillart P, Poupon MF. 2005. In vivo efficacy of STI571 in xenografted human small cell lung cancer alone or combined with chemotherapy. Int J Cancer 113: 849-856.

Demetri GD. 2011. Differential properties of current tyrosine kinase inhibitors in gastrointestinal stromal tumors. Semin Oncol 38: S10-S19. 
Demoulin J-B, Seo JK, Ekman S, Grapengiesser E, Hellman U, Rönnstrand L, Heldin C-H. 2003. Ligand-induced recruitment of $\mathrm{Na}^{+} / \mathrm{H}^{+}$exchanger regulatory factor to the PDGF (platelet-derived growth factor) receptor regulates actin cytoskeleton reorganization by PDGF. Biochem J 376: 505-510.

DiNitto JP, Deshmukh GD, Zhang Y, Jacques SL, Coli R, Worrall JW, Diehl W, English JM, Wu JC. 2010. Function of activation loop tyrosine phosphorylation in the mechanism of c-Kit auto-activation and its implication in sunitinib resistance. J Biochem 147: 601-609.

Di Pasquale G, Davidson BL, Stein CS, Martins I, Scudiero D, Monks A, Chiorini JA. 2003. Identification of PDGFR as a receptor for AAV-5 transduction. Nat Med 9: 13061312.

Dolloff NG, Shulby SS, Nelson AV, Stearns ME, Johannes GJ, Thomas JD, Meucci O, Fatatis A. 2005. Bone-metastatic potential of human prostate cancer cells correlates with Akt/PKB activation by $\alpha$ platelet-derived growth factor receptor. Oncogene 24: 6848-6854.

Easty DJ, Bennett DC. 2000. Protein tyrosine kinases in malignant melanoma. Melanoma Res 10: 401-411.

Ekman S, Rupp Thuresson E, Heldin C-H, Rönnstrand L 1999. Increased mitogenicity of an $\alpha \beta$ heterodimeric PDGF receptor complex correlates with lack of RasGAP binding. Oncogene 18: 2481-2488.

Elling C, Erben P, Walz C, Frickenhaus M, Schemionek M, Stehling M, Serve H, Cross NC, Hochhaus A, Hofmann WK, et al. 2011. Novel imatinib-sensitive PDGFRA-activating point mutations in hypereosinophilic syndrome induce growth factor independence and leukemia-like disease. Blood 117: 2935-2943.

Eriksson A, Siegbahn A, Westermark B, Heldin C-H, Claesson-Welsh L. 1992. PDGF $\alpha$ - and $\beta$-receptors activate unique and common signal transduction pathways. EMBO J 11: 543-550.

Faraone D, Aguzzi MS, Ragone G, Russo K, Capogrossi MC, Facchiano A. 2006. Heterodimerization of FGF-receptor 1 and PDGF-receptor- $\alpha$ : A novel mechanism underlying the inhibitory effect of PDGF-BB on FGF-2 in human cells. Blood 107: 1896-1902.

Fischer B, Marinov M, Arcaro A. 2007. Targeting receptor tyrosine kinase signalling in small cell lung cancer (SCLC): What have we learned so far? Cancer Treat Rev 33: 391-406.

Fleming TP, Saxena A, Clark WC, Robertson JT, Oldfield EH, Aaronson SA, Ali IU. 1992. Amplification and/or overexpression of platelet-derived growth factor receptors and epidermal growth factor receptor in human glial tumors. Cancer Res 52: 4550-4553.

Frost MJ, Ferrao PT, Hughes TP, Ashman LK. 2002. Juxtamembrane mutant V560GKit is more sensitive to Imatinib (STI571) compared with wild-type c-kit whereas the kinase domain mutant D816VKit is resistant. Mol Cancer Ther 1: 1115-1124.

Fruttiger M, Calver AR, Krüger WH, Mudhar HS, Michalovich D, Takakura N, Nishikawa SI, Richardson WD. 1996. PDGF mediates a neuron-astrocyte interaction in the developing retina. Neuron 17: 1117-1131.

Fruttiger M, Calver AR, Richardson WD. 2000. Platelet-derived growth factor is constitutively secreted from neuro- nal cell bodies but not from axons. Curr Biol 10: $1283-$ 1286.

Gerhardt H, Golding M, Fruttiger M, Ruhrberg C, Lundkvist A, Abramsson A, Jeltsch M, Mitchell C, Alitalo K, Shima D, et al. 2003. VEGF guides angiogenic sprouting utilizing endothelial tip cell filopodia. J Cell Biol 161: 1163-1177.

Gnessi L, Basciani S, Mariani S, Arizzi M, Spera G, Wang C, Bondjers C, Karlsson L, Betsholtz C. 2000. Leydig cell loss and spermatogenic arrest in platelet-derived growth factor (PDGF)-A-deficient mice. J Cell Biol 149: 1019-1026.

Golub TR, Barker GF, Lovett M, Gilliland DG. 1994. Fusion of PDGF receptor $\beta$ to a novel ets-like gene, tel, in chronic myelomonocytic leukemia with $\mathrm{t}(5 ; 12)$ chromosomal translocation. Cell 77: 307-316.

Gotzmann J, Fischer AN, Zojer M, Mikula M, Proell V, Huber $\mathrm{H}$, Jechlinger $M$, Waerner $T$, Weith $A$, Beug $H$, et al. 2006. A crucial function of PDGF in TGF- $\beta$-mediated cancer progression of hepatocytes. Oncogene 25: 3170-3185.

Griffin JH, Leung J, Bruner RJ, Caligiuri MA, Briesewitz R. 2003. Discovery of a fusion kinase in EOL-1 cells and idiopathic hypereosinophilic syndrome. Proc Natl Acad Sci 100: 7830-7835.

Hamilton TG, Klinghoffer RA, Corrin PD, Soriano P. 2003. Evolutionary divergence of platelet-derived growth factor $\alpha$ receptor signaling mechanisms. Mol Cell Biol 23: $4013-$ 4025.

Hansson GK. 2005. Inflammation, atherosclerosis, and coronary artery disease. N Engl J Med 352: 1685-1695.

Heidaran MA, Pierce JH, Jensen RA, Matsui T, Aaronson SA. 1990. Chimeric $\alpha$ - and $\beta$-platelet-derived growth factor (PDGF) receptors define three immunoglobulin-like domains of the $\alpha$-PDGF receptor that determine PDGF-AA binding specificity. J Biol Chem 265: 18741-18744.

Heinrich MC, Corless CL, Duensing A, McGreevey L, Chen CJ, Joseph N, Singer S, Griffith DJ, Haley A, Town A, et al. 2003. PDGFRA activating mutations in gastrointestinal stromal tumors. Science 299: 708-710.

Heissig B, Hattori K, Dias S, Friedrich M, Ferris B, Hackett NR, Crystal RG, Besmer P, Lyden D, Moore MA, et al. 2002. Recruitment of stem and progenitor cells from the bone marrow niche requires MMP-9 mediated release of kit-ligand. Cell 109: 625-637.

Heldin C-H, Westermark B. 1999. Mechanism of action and in vivo role of platelet-derived growth factor. Physiol Rev 79: 1283-1316.

Heldin C-H, Wasteson $\AA$, Westermark B. 1982. Interaction of platelet-derived growth factor with its fibroblast receptor. Demonstration of ligand degradation and receptor modulation. J Biol Chem 257: 4216-4221.

Heldin C-H, Östman A, Rönnstrand L. 1998. Signal transduction via platelet-derived growth factor receptors. Biochim Biophys Acta 1378: F79-F113.

Heldin C-H, Rubin K, Pietras K, Östman A. 2004. High interstitial fluid pressure-An obstacle in cancer therapy. Nat Rev Cancer 4: 806-813.

Hellberg C, Schmees C, Karlsson S, Åhgren A, Heldin C-H. 2009. Activation of protein kinase $C \alpha$ is necessary for sorting the PDGF $\beta$-receptor to Rab4a-dependent recycling. Mol Biol Cell 20: 2856-2863. 
Hellström M, Kalén M, Lindahl P, Abramsson A, Betsholtz C. 1999. Role of PDGF-B and PDGFR- $\beta$ in recruitment of vascular smooth muscle cells and pericytes during embryonic blood vessel formation in the mouse. Development 126: $3047-3055$.

Hermanson M, Funa K, Hartman M, Claesson-Welsh L, Heldin C-H, Westermark B, Nistér M. 1992. Platelet-derived growth factor and its receptors in human glioma tissue: Expression of messenger RNA and protein suggests the presence of autocrine and paracrine loops. Cancer Res 52: 3213-3219.

Hibi K, Takahashi T, Sekido Y, Ueda R, Hida T, Ariyoshi Y, Takagi H. 1991. Coexpression of the stem cell factor and the c-kit genes in small-cell lung cancer. Oncogene 6: 2291-2296.

Hoch RV, Soriano P. 2003. Roles of PDGF in animal development. Development 130: 4769-4784.

Hong L, Munugalavadla V, Kapur R. 2004. c-Kit-mediated overlapping and unique functional and biochemical outcomes via diverse signaling pathways. Mol Cell Biol 24: 1401-1410.

Huang EJ, Nocka KH, Buck J, Besmer P. 1992. Differential expression and processing of two cell associated forms of the kit-ligand: KL-1 and KL-2. Mol Biol Cell 3: 349-362.

Hubbard SR. 1997. Crystal structure of the activated insulin receptor tyrosine kinase in complex with peptide substrate and ATP analog. EMBO J 16: 5572-5581.

Hubbard SR. 2004. Juxtamembrane autoinhibition in receptor tyrosine kinases. Nat Rev Mol Cell Biol 5: 464-471

Huizinga JD, Thuneberg L, Kluppel M, Malysz J, Mikkelsen HB, Bernstein A. 1995. W/kit gene required for interstitial cells of Cajal and for intestinal pacemaker activity. Nature 373: 347-349.

Ikeda H, Kanakura Y, Tamaki T, Kuriu A, Kitayama H, Ishikawa J, Kanayama Y, Yonezawa T, Tarui S, Griffin JD. 1991. Expression and functional role of the proto-oncogene c-kit in acute myeloblastic leukemia cells. Blood 78: 2962-2968.

Irusta PM, Luo Y, Bakht O, Lai CC, Smith SO, DiMaio D. 2002. Definition of an inhibitory juxtamembrane WWlike domain in the platelet-derived growth factor $\beta$ receptor. J Biol Chem 277: 38627-38634.

Jackman DM, Johnson BE. 2005. Small-cell lung cancer. Lancet 366: 1385-1396.

Jayson GC, Parker GJ, Mullamitha S, Valle JW, Saunders M, Broughton L, Lawrance J, Carrington B, Roberts C, Issa B, et al. 2005. Blockade of platelet-derived growth factor receptor- $\beta$ by CDP860, a humanized, PEGylated diFab', leads to fluid accumulation and is associated with increased tumor vascularized volume. J Clin Oncol 23: 973-981.

Jechlinger M, Grunert S, Tamir IH, Janda E, Ludemann S, Waerner T, Seither P, Weith A, Beug H, Kraut N. 2003. Expression profiling of epithelial plasticity in tumor progression. Oncogene 22: 7155-7169.

Jechlinger M, Sommer A, Moriggl R, Seither P, Kraut N, Capodiecci P, Donovan M, Cordon-Cardo C, Beug H, Grunert S. 2006. Autocrine PDGFR signaling promotes mammary cancer metastasis. J Clin Invest 116: 1561 1570.
Jin K, Mao XO, Sun Y, Xie L, Greenberg DA. 2002. Stem cell factor stimulates neurogenesis in vitro and in vivo. J Clin Invest 110: 311-319.

Karlsson L, Bondjers C, Betsholtz C. 1999. Roles for PDGF$\mathrm{A}$ and sonic hedgehog in development of mesenchymal components of the hair follicle. Development 126: 26112621.

Karlsson L, Lindahl P, Heath JK, Betsholtz C. 2000. Abnormal gastrointestinal development in PDGF-A and PDGFR- $\alpha$ deficient mice implicates a novel mesenchymal structure with putative instructive properties in villus morphogenesis. Development 127: 3457-3466.

Karlsson S, Kowanetz K, Sandin A, Persson C, Östman A, Heldin C-H, Hellberg C. 2006. Loss of T-cell protein tyrosine phosphatase induces recycling of the plateletderived growth factor (PDGF) $\beta$-receptor but not the PDGF $\alpha$-receptor. Mol Biol Cell 17: 4846-4855.

Katafuchi T, Li AJ, Hirota S, Kitamura Y, Hori T. 2000. Impairment of spatial learning and hippocampal synaptic potentiation in c-kit mutant rats. Learn Mem 7: 383-392.

Kawaguchi N, Horiuchi K, Becherer JD, Toyama Y, Besmer P, Blobel CP. 2007. Different ADAMs have distinct influences on Kit ligand processing: Phorbol-ester-stimulated ectodomain shedding of Kitll by ADAM17 is reduced by ADAM19. J Cell Sci 120: 943-952.

Kimura Y, Jones N, Kluppel M, Hirashima M, Tachibana K, Cohn JB, Wrana JL, Pawson T, Bernstein A. 2004. Targeted mutations of the juxtamembrane tyrosines in the Kit receptor tyrosine kinase selectively affect multiple cell lineages. Proc Natl Acad Sci 101: 6015-6020.

Kissel H, Timokhina I, Hardy MP, Rothschild G, Tajima Y, Soares V, Angeles M, Whitlow SR, Manova K, Besmer P. 2000. Point mutation in kit receptor tyrosine kinase reveals essential roles for kit signaling in spermatogenesis and oogenesis without affecting other kit responses. EMBO J 19: 1312-1326.

Klinghoffer RA, Mueting-Nelsen PF, Faerman A, Shani M, Soriano P. 2001. The two PDGF receptors maintain conserved signaling in vivo despite divergent embryological functions. Mol Cell 7: 343-354.

Kozlowski M, Larose L, Lee F, Le DM, Rottapel R, Siminovitch KA. 1998. SHP-1 binds and negatively modulates the c-Kit receptor by interaction with tyrosine 569 in the c-Kit juxtamembrane domain. Mol Cell Biol 18: 20892099.

Krampert M, Heldin C-H, Heuchel R. 2008. A gain-of-function mutation in the PDGFR- $\beta$ alters the kinetics of injury response in liver and skin. Lab Invest 88: 1204-1214.

Kumabe T, Sohma Y, Kayama T, Yoshimoto T, Yamamoto T. 1992. Amplification of $\alpha$-platelet-derived growth factor receptor gene lacking an exon coding for a portion of the extracellular region in a primary brain tumor of glial origin. Oncogene 7: 627-633.

Lechleider RJ, Sugimoto S, Bennett AM, Kashishian AS, Cooper JA, Shoelson SE, Walsh CT, Neel BG. 1993. Activation of the $\mathrm{SH} 2$-containing phosphotyrosine phosphatase SH-PTP2 by its binding site, phosphotyrosine 1009, on the human platelet-derived growth factor receptor $\beta$. Biol Chem 268: 21478-21481.

Lemmon MA, Pinchasi D, Zhou M, Lax I, Schlessinger J. 1997. Kit receptor dimerization is driven by bivalent binding of stem cell factor. J Biol Chem 272: 6311-6317. 
Lennartsson J, Blume-Jensen P, Hermanson M, Pontén E, Carlberg M, Rönnstrand L. 1999. Phosphorylation of Shc by Src family kinases is necessary for stem cell factor receptor/c-kit mediated activation of the Ras/MAP kinase pathway and c-fos induction. Oncogene 18: 55465553.

Lennartsson J, Wardega P, Engström U, Hellman U, Heldin C-H. 2006. Alix facilitates the interaction between c-Cbl and platelet-derived growth factor $\beta$-receptor and thereby modulates receptor downregulation. J Biol Chem 281: 39152-39158.

Levéen P, Pekny M, Gebre-Medhin S, Swolin B, Larsson E, Betsholtz C. 1994. Mice deficient for PDGF B show renal, cardiovascular, and hematological abnormalities. Genes Dev 8: 1875-1887.

Li L, Heldin C-H, Heldin P. 2006. Inhibition of plateletderived growth factor-BB-induced receptor activation and fibroblast migration by hyaluronan activation of CD44. J Biol Chem 281: 26512-26519.

Lidén A, Berg A, Nedrebø T, Reed RK, Rubin K. 2006. Platelet-derived growth factor BB-mediated normalization of dermal interstitial fluid pressure after mast cell degranulation depends on $\beta 3$ but not $\beta 1$ integrins. Circulation Res 98: 635-641.

Lindahl P, Johansson BR, Levéen P, Betsholtz C. 1997a. Pericyte loss and microaneurysm formation in PDGF-B-deficient mice. Science 277: 242-245.

Lindahl P, Karlsson L, Hellström M, Gebre-Medhin S, Willetts K, Heath JK, Betsholtz C. 1997b. Alveogenesis failure in PDGF-A-deficient mice is coupled to lack of distal spreading of alveolar smooth muscle cell progenitors during lung development. Development 124: 3943-3953.

Lindahl P, Hellström M, Kalén M, Karlsson L, Pekny M, Pekna M, Soriano P, Betsholtz C. 1998. Paracrine PDGF-B/PDGF-R $\beta$ signaling controls mesangial cell development in kidney glomeruli. Development 125: 3313 3322.

Litz J, Sakuntala Warshamana-Greene G, Sulanke G, Lipson KE, Krystal GW. 2004. The multi-targeted kinase inhibitor SU5416 inhibits small cell lung cancer growth and angiogenesis, in part by blocking Kit-mediated VEGF expression. Lung Cancer 46: 283-291.

Lokker NA, O’Hare JP, Barsoumian A, Tomlinson JE, Ramakrishnan V, Fretto LJ, Giese NA. 1997. Functional importance of platelet-derived growth factor (PDGF) receptor extracellular immunoglobulin-like domains. Identification of PDGF binding site and neutralizing monoclonal antibodies. J Biol Chem 272: 33037-33044.

Longley BJ, Tyrrell L, Ma Y, Williams DA, Halaban R, Langley K, Lu HS, Schechter NM. 1997. Chymase cleavage of stem cell factor yields a bioactive, soluble product. Proc Natl Acad Sci 94: 9017-9021.

Loukinova E, Ranganathan S, Kuznetsov S, Gorlatova N, Migliorini MM, Loukinov D, Ulery PG, Mikhailenko I, Lawrence DA, Strickland DK. 2002. Platelet-derived growth factor (PDGF)-induced tyrosine phosphorylation of the low density lipoprotein receptor-related protein (LRP). Evidence for integrated co-receptor function betwenn LRP and the PDGF. J Biol Chem 277: 1549915506.

Lyford GL, He CL, Soffer E, Hull TL, Strong SA, Senagore AJ, Burgart LJ, Young-Fadok T, Szurszewski JH, Farrugia
G. 2002. Pan-colonic decrease in interstitial cells of Cajal in patients with slow transit constipation. Gut 51: 496501.

Ma Y, Zeng S, Metcalfe DD, Akin C, Dimitrijevic S, Butterfield JH, McMahon G, Longley BJ. 2002. The c-KIT mutation causing human mastocytosis is resistant to STI571 and other KIT kinase inhibitors; kinases with enzymatic site mutations show different inhibitor sensitivity profiles than wild-type kinases and those with regulatorytype mutations. Blood 99: 1741-1744.

Magnusson MK, Meade KE, Brown KE, Arthur DC, Krueger LA, Barrett AJ, Dunbar CE. 2001. Rabaptin-5 is a novel fusion partner to platelet-derived growth factor $\beta$ receptor in chronic myelomonocytic leukemia. Blood 98: 2518-2525.

Masson K, Heiss E, Band H, Rönnstrand L. 2006. Direct binding of Cbl to Tyr568 and Tyr936 of the stem cell factor receptor/c-Kit is required for ligand-induced ubiquitination, internalization and degradation. Biochem J 399: 5-67.

Maudsley S, Zamah AM, Rahman N, Blitzer JT, Luttrell LM, Lefkowitz RJ, Hall RA. 2000. Platelet-derived growth factor receptor association with $\mathrm{Na}^{+} / \mathrm{H}^{+}$exchanger regulatory factor potentiates receptor activity. Mol Cell Biol 20: 8352-8363.

Minami A, Mizutani K, Waseda M, Kajita M, Miyata M, Ikeda W, Takai Y. 2010. Necl-5/PVR enhances PDGFinduced attraction of growing microtubules to the plasma membrane of the leading edge of moving NIH3T3 cells. Genes Cells 15: 1123-1135.

Miyake S, Mullane-Robinson KP, Lill NL, Douillard P, Band H. 1999. Cbl-mediated negative regulation of plateletderived growth factor receptor-dependent cell proliferation-A critical role for Cbl tyrosine kinase-binding domain. J Biol Chem 274: 16619-16628.

Miyazawa K, Toyama K, Gotoh A, Hendrie PC, Mantel C, Broxmayer HE. 1994. Ligand-dependent polyubiquitination of c-kit product: A possible mechanism of receptor down regulation in M107e cells. Blood 83: 137-145.

Miyazawa K, Bäckström G, Leppänen O, Persson C, Wernstedt C, Hellman U, Heldin C-H, Östman A. 1998. Role of immunoglobulin-like domains 2-4 of the platelet-derived growth factor $\alpha$-receptor in ligand-receptor complex assembly. J Biol Chem 273: 25495-25502.

Mol CD, Lim KB, Sridhar V, Zou H, Chien EY, Sang BC, Nowakowski J, Kassel DB, Cronin CN, McRee DE. 2003. Structure of a c-kit product complex reveals the basis for kinase transactivation. J Biol Chem 278: 31461-31464.

Mol CD, Dougan DR, Schneider TR, Skene RJ, Kraus ML, Scheibe DN, Snell GP, Zou H, Sang BC, Wilson KP. 2004 Structural basis for the autoinhibition and STI-571 inhibition of c-Kit tyrosine kinase. J Biol Chem 279: 3165531663.

Mori S, Heldin C-H, Claesson-Welsh L. 1992. Ligand-induced polyubiquitination of the platelet-derived growth factor $\beta$-receptor. J Biol Chem 267: 6429-6434.

Motro B, Wojtowicz JM, Bernstein A, van der Kooy D. 1996. Steel mutant mice are deficient in hippocampal learning but not long-term potentiation. Proc Natl Acad Sci 93: $1808-1813$.

O’Brien KP, Seroussi E, Dal Cin P, Sciot R, Mandahl N, Fletcher JA, Turc-Carel C, Dumanski JP. 1998. Various 
regions within the $\alpha$-helical domain of the COL1A1 gene are fused to the second exon of the PDGFB gene in dermatofibrosarcomas and giant-cell fibroblastomas. Gene Chrom Cancer 23: 187-193.

Odenike O, Thirman MJ, Artz AS, Godley LA, Larson RA, Stock W. 2011. Gene mutations, epigenetic dysregulation, and personalized therapy in myeloid neoplasia: Are we there yet? Semin Oncol 38: 196-214.

Ogawa M, Matsuzaki Y, Nishikawa S, Hayashi S, Kunisada T, Sudo T, Kina T, Nakauchi H. 1991. Expression and function of c-kit in hemopoietic progenitor cells. J Exp Med 174: $63-71$.

Ohlsson R, Falck P, Hellström M, Lindahl P, Boström H, Franklin G, Ährlund-Richter L, Pollard J, Soriano P, Besholtz C. 1999. PDGFB regulates the development of the labyrinthine layer of the mouse fetal placenta. Dev Biol 212: 124-136.

Oliveira SH, Lukacs NW. 2003. Stem cell factor: A hemopoietic cytokine with important targets in asthma. Curr Drug Targets Inflamm Allergy 2: 313-318.

Olson LE, Soriano P. 2009. Increased PDGFR $\alpha$ activation disrupts connective tissue development and drives systemic fibrosis. Dev Cell 16: 303-313.

Omura T, Heldin C-H, Östman A. 1997. Immunoglobulinlike domain 4-mediated receptor-receptor interactions contribute to platelet-derived growth factor-induced receptor dimerization. J Biol Chem 272: 12676-12682.

Pardanani A, Ketterling RP, Brockman SR, Flynn HC, Paternoster SF, Shearer BM, Reeder TL, Li CY, Cross NC, Cools J, et al. 2003. CHIC2 deletion, a surrogate for FIP1L1PDGFRA fusion, occurs in systemic mastocytosis associated with eosinophilia and predicts response to imatinib mesylate therapy. Blood 102: 3093-3096.

Paulson RF, Vesely S, Siminovitch KA, Bernstein A. 1996. Signalling by the $W /$ Kit receptor tyrosine kinase is negatively regulated in vivo by the protein tyrosine phosphatase Shp1. Nat Genet 13: 309-315.

Pietras K, Sjöblom T, Rubin K, Heldin C-H, Östman A. 2003. PDGF receptors as cancer drug targets. Cancer Cell 3: 439-443.

Pietras K, Pahler J, Bergers G, Hanahan D. 2008. Functions of paracrine PDGF signaling in the proangiogenic tumor stroma revealed by pharmacological targeting. PLoS Med 5: e19.

Puputti M, Tynninen O, Sihto H, Blom T, Maenpaa H, Isola J, Paetau A, Joensuu H, Nupponen NN. 2006. Amplification of KIT, PDGFRA, VEGFR2, and EGFR in gliomas. Mol Cancer Res 4: 927-934.

Reith AD, Ellis C, Lyman SD, Anderson DM, Williams DW, Bernstein A, Pawson T. 1991. Signal transduction by normal isoforms and $W$ mutant variants of the Kit receptor tyrosine kinase. EMBO J 10: 2451-2459.

Robson MC, Phillips LG, Thomason A, Robson LE, Pierce GF. 1992. Platelet-derived growth factor BB for the treatment of chronic pressure ulcers. Lancet 339: 23-25.

Rodt SÅ, Åhlén K, Berg A, Rubin K, Reed RK. 1996. A novel physiological function for platelet-derived growth factorBB in rat dermis. J Physiol 495: 193-200.

Rolny C, Nilsson I, Magnusson P, Armulik A, Jakobsson L, Wentzel P, Lindblom P, Norlin J, Betsholtz C, Heuchel R, et al. 2006. Platelet-derived growth factor receptor- $\beta$ pro- motes early endothelial cell differentiation. Blood 108: 1877-1886.

Ross R. 1993. The pathogenesis of atherosclerosis: A perspective for the 1990s. Nature 362: 801-809.

Rossi P, Dolci S, Sette C, Geremia R. 2003. Molecular mechanisms utilized by alternative c-kit gene products in the control of spermatogonial proliferation and sperm-mediated egg activation. Andrologia 35: 71-78.

Russell MR, Jamieson WL, Dolloff NG, Fatatis A. 2009. The $\alpha$-receptor for platelet-derived growth factor as a target for antibody-mediated inhibition of skeletal metastases from prostate cancer cells. Oncogene 28: 412-421.

Saito Y, Haendeler J, Hojo Y, Yamamoto K, Berk BC. 2001. Receptor heterodimerization: Essential mechanism for platelet-derived growth factor-induced epidermal growth factor receptor transactivation. Mol Cell Biol 21: 63876394.

Sattler M, Salgia R, Shrikhande G, Verma S, Pisick E, Prasad KV, Griffin JD. 1997. Steel factor induces tyrosine phosphorylation of CRKL and binding of CRKL to a complex containing c-kit, phosphatidylinositol 3-kinase, and p120(CBL). J Biol Chem 272: 10248-10253.

Schmees C, Villaseñor R, Zheng W, Ma H, Zerial M, Heldin C-H, Hellberg C. 2012. Macropinocytosis of the PDGF $\beta$-receptor promotes fibroblast transformation by $\mathrm{H}$ RasG12V. Mol Biol Cell 23: 2571-2582.

Schneller M, Vuori K, Ruoslahti E. 1997. $\alpha \mathrm{v} \beta 3$ integrin associates with activated insulin and PDGF $\beta$ receptors and potentiates the biological activity of PDGF. EMBO J 16: $5600-5607$.

Sette C, Bevilacqua A, Bianchini A, Mangia F, Geremia R, Rossi P. 1997. Parthenogenetic activation of mouse eggs by microinjection of a truncated c-kit tyrosine kinase present in spermatozoa. Development 124: 2267-2274.

Shim AH, Liu H, Focia PJ, Chen X, Lin PC, He X. 2010. Structures of a platelet-derived growth factor/propeptide complex and a platelet-derived growth factor/receptor complex. Proc Natl Acad Sci 107: 11307-11312.

Shimizu A, O’Brien KP, Sjöblom T, Pietras K, Buchdunger E, Collins VP, Heldin C-H, Dumanski JP, Östman A. 1999. The dermatofibrosarcoma protuberans-associated collagen type I $\alpha 1 /$ platelet-derived growth factor (PDGF) Bchain fusion gene generates a transforming protein that is processed to functional PDGF-BB. Cancer Res 59: 37193723.

Simon M-P, Pedeutour F, Sirvent N, Grosgeorge J, Minoletti F, Coindre J-M, Terrier-Lacombe M-J, Mandahl N, Craver $\mathrm{RD}$, Blin N, et al. 1997. Deregulation of the platelet-derived growth factor B-chain gene via fusion with collagen gene COL1A1 in dermatofibrosarcoma protuberans and giant-cell fibroblastoma. Nat Genet 15: 95-98.

Smith JS, Wang XY, Qian J, Hosek SM, Scheithauer BW, Jenkins RB, James CD. 2000. Amplification of the platelet-derived growth factor receptor-A (PDGFRA) gene occurs in oligodendrogliomas with grade IV anaplastic features. J Neuropathol Exp Neurol 59: 495-503.

Song S, Ewald AJ, Stallcup W, Werb Z, Bergers G. 2005. PDGFR $\beta^{+}$perivascular progenitor cells in tumours regulate pericyte differentiation and vascular survival. Nat Cell Biol 7: 870-879. 
Soriano P. 1994. Abnormal kidney development and hematological disorders in PDGF $\beta$-receptor mutant mice. Genes Dev 8: 1888-1896.

Soriano P. 1997. The PDGF $\alpha$ receptor is required for neural crest cell development and for normal patterning of the somites. Development 124: 2691-2700.

Sorkin A, Westermark B, Heldin C-H, Claesson-Welsh L. 1991. Effect of receptor kinase inactivation on the rate of internalization and degradation of PDGF and the PDGF $\beta$-receptor. J Cell Biol 112: 469-478.

Soroceanu L, Akhavan A, Cobbs CS. 2008. Platelet-derived growth factor- $\alpha$ receptor activation is required for human cytomegalovirus infection. Nature 455: 391-395.

Spritz RA. 1994. Molecular basis of human piebaldism. $J$ Invest Dermatol 103: 137S-140S.

Stover EH, Chen J, Folens C, Lee BH, Mentens N, Marynen P, Williams IR, Gilliland DG, Cools J. 2006. Activation of FIP1L1-PDGFR $\alpha$ requires disruption of the juxtamembrane domain of PDGFR $\alpha$ and is FIP1L1-independent. Proc Natl Acad Sci 103: 8078-8083.

Sundaresan M, Yu ZX, Ferrans VJ, Irani K, Finkel T. 1995. Requirement for generation of $\mathrm{H}_{2} \mathrm{O}_{2}$ for platelet-derived growth factor signal transduction. Science 270: 296-299.

Sundberg C, Rubin K. 1996. Stimulation of $\beta_{1}$ integrins on fibroblasts induces PDGF independent tyrosine phosphorylation of PDGF $\beta$-receptors. J Cell Biol 132: 741752.

Takahashi Y, Morales FC, Kreimann EL, Georgescu MM. 2006. PTEN tumor suppressor associates with NHERF proteins to attenuate PDGF receptor signaling. EMBO J 25: 910-920.

Tallquist MD, Soriano P. 2003. Cell autonomous requirement for PDGFR $\alpha$ in populations of cranial and cardiac neural crest cells. Development 130: 507-518.

Tallquist MD, Weismann KE, Hellstrom M, Soriano P. 2000. Early myotome specification regulates PDGFA expression and axial skeleton development. Development 127: 5059-5070.

Theisen CS, Wahl JK III, Johnson KR, Wheelock MJ. 2007. NHERF links the N-cadherin/catenin complex to the platelet-derived growth factor receptor to modulate the actin cytoskeleton and regulate cell motility. Mol Biol Cell 18: $1220-1232$.

Thiery JP, Acloque H, Huang RY, Nieto MA. 2009. Epithelial-mesenchymal transitions in development and disease. Cell 139: 871-890.

Timokhina I, Kissel H, Stella G, Besmer P. 1998. Kit signaling through PI3-kinase and Src kinase pathways: An essential role for Racl and JNK activation in mast cell proliferation. $E M B O J$ J 17: 6250-6262.

Toffalini F, Hellberg C, Demoulin J-B. 2010. Critical role of the platelet-derived growth factor receptor (PDGFR) $\beta$ transmembrane domain in the TEL-PDGFR $\beta$ cytosolic oncoprotein. J Biol Chem 285: 12268-12278.

Ueda S, Mizuki M, Ikeda H, Tsujimura T, Matsumura I, Nakano K, Daino H, Honda Zi Z, Sonoyama J, Shibayama H, et al. 2002. Critical roles of c-Kit tyrosine residues 567 and 719 in stem cell factor-induced chemotaxis: Contribution of src family kinase and PI3-kinase on calcium mobilization and cell migration. Blood 99: 3342-3349.
Ustun C, DeRemer DL, Akin C. 2011. Tyrosine kinase inhibitors in the treatment of systemic mastocytosis. Leuk Res 35: 1143-1152.

Van den Akker NM, Winkel LC, Nisancioglu MH, Maas S, Wisse LJ, Armulik A, Poelmann RE, Lie-Venema H, Betsholtz C, Gittenberger-de Groot AC. 2008. PDGF-B signaling is important for murine cardiac development: Its role in developing atrioventricular valves, coronaries, and cardiac innervation. Dev Dyn 237: 494-503.

Wang L, Vargas H, French SW. 2000. Cellular origin of gastrointestinal stromal tumors: A study of 27 cases. Arch Pathol Lab Med 124: 1471-1475.

Wang Y, Pennock SD, Chen X, Kazlauskas A, Wang Z. 2004. Platelet-derived growth factor receptor-mediated signal transduction from endosomes. J Biol Chem 279: 80388046.

Ward SM, Burns AJ, Torihashi S, Harney SC, Sanders KM. 1995. Impaired development of interstitial cells and intestinal electrical rhythmicity in steel mutants. Am J Physiol 269: C1577-C1585.

Wehrle-Haller B. 2003. The role of Kit-ligand in melanocyte development and epidermal homeostasis. Pigment Cell Res 16: 287-296.

Wisniewski D, Strife A, Clarkson B. 1996. c-kit ligand stimulates tyrosine phosphorylation of the $\mathrm{c}-\mathrm{Cbl}$ protein in human hematopoietic cells. Leukemia 10: 1436-1442.

Wolff NC, Randle DE, Egorin MJ, Minna JD, Ilaria RL Jr. 2004. Imatinib mesylate efficiently achieves therapeutic intratumor concentrations in vivo but has limited activity in a xenograft model of small cell lung cancer. Clin Cancer Res 10: 3528-3534.

Woodruff RH, Fruttiger M, Richardson WD, Franklin RJ. 2004. Platelet-derived growth factor regulates oligodendrocyte progenitor numbers in adult CNS and their response following CNS demyelination. Mol Cell Neurosci 25: $252-262$.

Voytyuk O, Lennartsson J, Mogi A, Caruana G, Courtneidge SA, Ashman LK, Rönnstrand L. 2003. Src family kinases are involved in the differential signaling from two splice forms of c-Kit. J Biol Chem 278: 9159-9166.

Wybenga-Groot LE, Baskin B, Ong SH, Tong J, Pawson T, Sicheri F. 2001. Structural basis for autoinhibition of the EphB2 receptor tyrosine kinase by the unphosphorylated juxtamembrane region. Cell 106: 745-757.

Xie J, Aszterbaum M, Zhang X, Bonifas JM, Zachary C, Epstein E, McCormick F. 2001. A role of PDGFR $\alpha$ in basal cell carcinoma proliferation. Proc Natl Acad Sci 98: 9255-9259.

Xu X, Bringas P Jr, Soriano P, Chai Y. 2005. PDGFR- $\alpha$ signaling is critical for tooth cusp and palate morphogenesis. Dev Dyn 232: 75-84.

Yang Y, Yuzawa S, Schlessinger J. 2008. Contacts between membrane proximal regions of the PDGF receptor ectodomain are required for receptor activation but not for receptor dimerization. ProcNatlAcad Sci 105: 7681-7686.

Yee NS, Hsiau CW, Serve H, Vosseller K, Besmer P. 1994. Mechanism of down-regulation of c-kit receptor. Roles of receptor tyrosine kinase, phosphatidylinositol 3'-kinase, and protein kinase C. J Biol Chem 269: 31991-31998.

Yuzawa S, Opatowsky Y, Zhang Z, Mandiyan V, Lax I, Schlessinger J. 2007. Structural basis for activation of the recep- 
tor tyrosine kinase KIT by stem cell factor. Cell 130: 323-334.

Zadjali F, Pike AC, Vesterlund M, Sun J, Wu C, Li SS, Rönnstrand L, Knapp S, Bullock AN, Flores-Morales A. 2011. Structural basis for c-KIT inhibition by the suppressor of cytokine signaling 6 (SOCS6) ubiquitin ligase. J Biol Chem 286: $480-490$.

Zeng S, Xu Z, Lipkowitz S, Longley JB. 2005. Regulation of stem cell factor receptor signaling by $\mathrm{Cbl}$ family proteins (Cbl-b/c-Cbl). Blood 105: 226-232.
Zhang Z, Zhang R, Joachimiak A, Schlessinger J, Kong XP. 2000. Crystal structure of human stem cell factor: Implication for stem cell factor receptor dimerization and activation. Proc Natl Acad Sci 97: 7732-7737.

Zhao J, Roth J, Bode-Lesniewska B, Pfaltz M, Heitz PU, Komminoth P. 2002. Combined comparative genomic hybridization and genomic microarray for detection of gene amplifications in pulmonary artery intimal sarcomas and adrenocortical tumors. Gene Chromosome Canc 34: 48-57. 


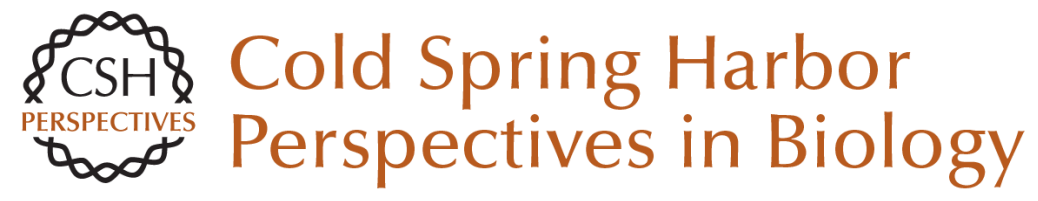

\section{Structural and Functional Properties of Platelet-Derived Growth Factor and Stem Cell Factor Receptors}

Carl-Henrik Heldin and Johan Lennartsson

Cold Spring Harb Perspect Biol 2013; doi: 10.1101/cshperspect.a009100

Subject Collection Signaling by Receptor Tyrosine Kinases

CSF-1 Receptor Signaling in Myeloid Cells

E. Richard Stanley and Violeta Chitu

The EGFR Family: Not So Prototypical Receptor

Tyrosine Kinases

Mark A. Lemmon, Joseph Schlessinger and

Kathryn M. Ferguson

Tie2 and Eph Receptor Tyrosine Kinase Activation and Signaling

William A. Barton, Annamarie C. Dalton, Tom C.M.

Seegar, et al.

The Spatiotemporal Organization of ErbB

Receptors: Insights from Microscopy

Christopher C. Valley, Keith A. Lidke and Diane S. Lidke

Insulin Receptor Signaling in Normal and Insulin-Resistant States

Jérémie Boucher, André Kleinridders and C. Ronald Kahn

Central Role of RET in Thyroid Cancer

Massimo Santoro and Francesca Carlomagno

Receptor Tyrosine Kinase-Mediated Angiogenesis Michael Jeltsch, Veli-Matti Leppänen, Pipsa Saharinen, et al.
The Genesis of Tyrosine Phosphorylation Tony Hunter

Structure-Function Relationships of ErbB RTKs in the Plasma Membrane of Living Cells Donna J. Arndt-Jovin, Michelle G. Botelho and Thomas M. Jovin

Receptor Tyrosine Kinases: Legacy of the First Two Decades Joseph Schlessinger

The Role of Ryk and Ror Receptor Tyrosine Kinases in Wnt Signal Transduction Jennifer Green, Roel Nusse and Renée van Amerongen

Regulation of Receptor Tyrosine Kinase Ligand Processing Colin Adrain and Matthew Freeman

Molecular Mechanisms of SH2- and PTB-Domain-Containing Proteins in Receptor Tyrosine Kinase Signaling Melany J. Wagner, Melissa M. Stacey, Bernard A. Liu, et al.

Eph Receptor Signaling and Ephrins Erika M. Lisabeth, Giulia Falivelli and Elena B. Pasquale

For additional articles in this collection, see http://cshperspectives.cshlp.org/cgi/collection/

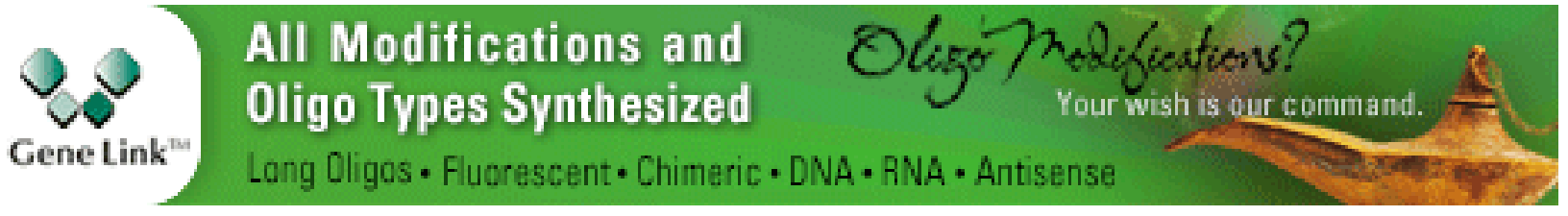




\section{Biology of the TAM Receptors \\ Greg Lemke}

Effects of Membrane Trafficking on Signaling by

Receptor Tyrosine Kinases

Marta Miaczynska

For additional articles in this collection, see http://cshperspectives.cshlp.org/cgi/collection/

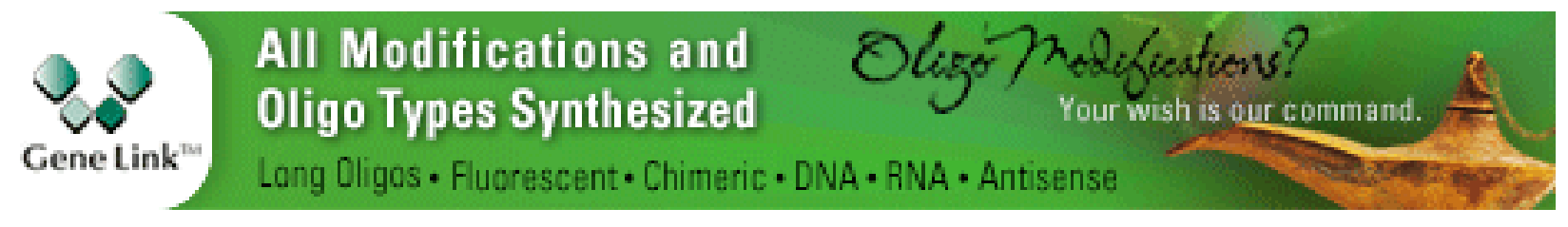

Copyright @ 2013 Cold Spring Harbor Laboratory Press; all rights reserved 